\title{
Co-Management: Social communications' gaps of Coastal Tourism in Seribu Islands
}

\author{
Hengky, S. H. \\ Director, SHINE Institute, Associate Professor \\ Triguna, School of Economics, Department of Business Management, Indonesia \\ Tel: 62-896-5704-5738Ｅ-mail: hengky_halim@yahoo.com.au
}

$\begin{array}{lr}\text { Received: October 6, } 2015 & \text { Accepted: October 25, } 2015 \\ \text { doi:10.5296/emsd.v4i2.8524 } & \text { URL: http://dx.doi.org/10.5296/emsd.v4i2.8524 }\end{array}$

\begin{abstract}
This study was conducted to respond the statement of the Coordinating Minister for Maritime and Resources, city government, and the central government, who planned to settle down the Seribu islands, becomes a center of marine travel in Indonesia by developing the infrastructure, increasing an environment awareness, and strengthening community empowerment. Factually, environment awareness becomes the main issues on the island. Based on the social-communication, which is one of six domains of co-management, is considered relevant to enhance the program on the island. This research aim is to find out the social communications gaps on implementing co-management of the coastal tourism management in the islands. Based on the research tabulation, the study found that there is a significant gap (33.5\%) of communal communications. The government could decrease the gap by aligning the priority of the social communications by using the people-centered on supporting the program. It would be done by starting their priority became interactional learning, training sustainable coastal tourism, and raising public awareness. At the same time, the government informing the program aim by using social media, and inviting to the local community on an interactive learning program that would accommodate their ideas.
\end{abstract}

Keywords: Social communication, Co-management, Interactive learning, Informing, Raising awareness, Training

\section{Introduction}

In 2013, the tourism industry revenue reached 10 million US dollars. Last years the number increased to USD 11 million (Mediana, 2015), and the number of international tourists visiting Indonesia in February 2015 increased by 11.95 percent compared to previous years (Win, 2015). 
This year, the government is targeting to earn income from tourism amounted to the USD 12 billion, because in 2013, it only produced the USD 10 billion, whereas in 2014 increased to the USD 11 billion. Additionally, in 2019 later, they plant it donations of foreign exchange from tourism reached USD 20 billion (Sukmana, 2015).

Transport access to the Seribu islands, the government has set up a dock at the port of Kali Adem. "Muara Angke" is the main gate from the North side Jakarta. Tourists also could use a common charter of a ship up the Fishing Port Muara Angke, and charter-boat, which previously was transformed into a passenger ship with a capacity of up to 100 people (Wahono, 2015).

The island, is one of the favourite destinations around Jakarta that promotes coastal-tourism, and it continues to improve. The area consists of 110 islands with a population of 24,000, and it continues to develop its tourism better. It is also a national park of the islands that covering an area of 107,489 hectares. There is also a National Park namely "Pulau Seribu" National Park. The Park has the habitat of 24 families of flora, 169 species of fish, reptiles that include turtles, pythons and monitor lizards, as well as 24 species of birds (Kuslum, 2015).

There is now a very significant development in the islands, especially on the coastal-tourism. It reflected from the number of tourists who visited in. In 2013, it visited by 1.45 million tourists, and in 2014, it increased to about 2.9 million tourists. The situation was encouraging the growth of new lodging and dining. Home-stay carrying amount increased from the year 2010 as many as 92 units to 278 units. In 2012, the restaurant increased from 47 units to 56 units (Wahyuni, 2013; Jal, 2015b).

In addition, to visits from the number of tourists, the progress of the islands can be seen from the development undertaken. Various infrastructures that supported tourism are also being developed such as built three floors' hotel in 2014. The development of tourism in the islands takes the role of diverse parties as the role of government and the private sector. The work was to be carried out together, especially between government and the private sector.

Meanwhile, Coordinating Minister for Marine and Resources, encourages governments to make the islands' region became a center of marine travel in Indonesia. According to him, the islands have a great potential of a coastal-tourism that would increase the number of domestic and international tourists. The ministry also fully supports the program of the city government on developing the infrastructure, increasing an environment awareness, and strengthening community empowerment. Besides, he plans to build the airport, port, power plant, and the accommodation (Rachman, 2015).

Moreover, the central government will extend the airport runway on Long Island from 800 meters to 1,500 meters. The infrastructure will be equipped with the construction of several ports in the islands. Jakarta Governor promises the Islands' District will develop into a tourist region of international standard.

Responding the statement of the Coordinating Minister for maritime and Resources, city government, and the central government on settling their program, this research aim is to find out the social communication gaps on implementing co-management of the coastal tourism's 
management in the islands.

\section{Literature Review}

\subsection{Co-management}

Co-management or collaborative management, is often referred to as a joint management, participatory-management, shared-management, multi-stakeholder management or roundtable agreement. The term co-management is defined as cooperative management, consultative-management, and constructive management (Carlsson \& Berkes, 2005).

In the context of natural resources, environmental management in the long term can be understood as the right to regulate the use or internal use of natural resources and convert these resources by making improvements management. This activity can be realized by a single perpetrator or joint and several groups of individuals or cooperation between different groups (Ostrom and Schlager, 1996).

\subsection{Social Communications}

Co-management approach began to emerge in the early 1980s in America and Europe and become the new paradigm for the management of natural resources in Indonesia due to the demands on decentralization of the response. IUCN (1994) explains the basic idea of collaborative management is a partnership between government agencies, local communities and resource users, non-governmental organizations and other interest groups in negotiating and determining the appropriate framework of authority, and responsible for the specific area or management partnership of so-called co-management.

Moreover, there are six domains on contributing, understanding, and practicing co-management (Borrini-Feyerrabend, Farhar, Nguinguiri, \& Ndangang, 2007). One of them is social communications that would be discussed in this study:

- Informing

- Raising awareness

- Training

- Interactive learning

\subsection{Informing}

Informing, that covers the field of public-relations, communications, and promotions. In general, this is seen as a sub-field of communication involved in the "Communication's destination" with an emphasis on strategy rather than tactics. Social communication can be carried out by non-governmental organizations and governments as well as corporations and institutions, namely the role normally sphere of communication or public affairs department, working in concert with other departments to develop communication strategies that reflect the overall organizational plan which covers a mission, vision, and purpose (Carlsson \& Berkes, 2005).

Although it has been suggested that the traditional mass media campaigns, in many cases, they did not effective for informing, reaching, and influencing the community preference (Petty, Brisnol, \& Priester, 2009). It appears that the government keeps trying to convey their 
information through the mechanism of allocation of communication through the mass media to the citizens, and it will only provide little opportunity for the residents to start their dialogue with the agents of change behind the government's campaign (Weiss \& Tschirhart, 2007).

Moreover, multi-pronged communication strategy: a national campaign focused on raising awareness of protecting the environment in a sustainable manner and informing people about the program. Interpersonal communication is the main source of information, although television, radio, posters and pamphlets, are also used (UNICEF, 2005).

The World Leisure Organization (2008) suggested the researchers and academics to focus on addressing and disseminating the findings as a way of improving, enhancing and informed professional practice, and understanding of the phenomena of all forms of the information about the nature of freedom. They can use it to improve their knowledge and the information to the relevant institutions in decision-making as well as local and national policies.

However, Bandura (2001) argues: "The absence of individualized guidance limits the power of one-way mass communications," made the campaign ineffective. Communication is a research-driven consultation process involved planning, designing, and implementing of strategic interventions. The availability of information relevant and adequate motivation will have an impact on the attitudes and behavior of individuals or communities that involves monitoring changes in their attitudes and behavior (Barwick, Phipps, Johnny, \& Myers, 2014).

\subsection{Raising Awareness}

Social mobilization is the process of participation partners' cross-sector easy and practical to determine needs and raise awareness and desire of development with the participation of actors, including institutions, groups, community networks, identify, improve and manage human resources and of environmental, thereby strengthening self-reliance and sustainability of achievements would increase communications initiative to increase public awareness, but less creating lasting social change. Its impact on sustainable behavior change between the individual and society at large, need a participatory strategy (UNICEF, 2005).

Increasing social awareness and acceptance by the community in a reinforcement program of tourism and environmental conservation is indispensable. In addition, broader participation of all relevant sectors involved in the tourism industry is in desperate need of local community participation. Raising awareness among the new generation can be formed through education with the concept of sustainable coastal tourism. This concept will increase national values, social-norms, culture, and environment in order to show respect, care and preservation of their natural surroundings. This will increase the social-awareness of the coastal-tourism program based society (Dagron \& Tufte, 2006).

To create awareness of the value of heritage is one of the main objectives of the commission on sustainable tourism in the conservation of the environment and local culture. In an effort to support this trend, the Commission provides financial assistance to support the conservation program by clarifying program, mechanism, registration, and monitoring of the 
traditional heritage homes, and also makes the restoration of property rights to them (Aall, 2014).

However, through partnerships and bilateral agreements, the commission tried to promote the programs and activities of sustainable tourism as a state program for economical organizations as a source of local revenue, and this aspect of achieving balanced growth in the economics activity, environmental conservation and cultural entrepreneur depend on the awareness of the coastal-tourism (Aall, 2014; and Dagron \& Tufte, 2006).

\subsection{Training}

The training involves a variety of community participation, and local governments can facilitate skills are effective. In addition, these activities can increase awareness-raising activities and communication between citizens and government. Skills training volunteers in participatory programs can collect an information about the social, economic, environmental and government policy effectiveness (UNICEF, 2005).

However, training is one of the effective intervention efforts, and most commonly performed in the form of training to deal with behavioral problems that environmentally destructive. The training covers the environmental conservation efforts and evaluation activities, and development of a procedure in sustainable development programs with the help of an interpretation (Tiger, Hanley, \& Bruzek, 2008).

\subsection{Interactive learning}

In order to understand public attitudes in interactive learning, the perceived benefits arise out of the learning process that is influenced by interactive-learning environment. The result can be felt in the success of one's skills and knowledge enhancement. The perceived success of this learning can be affected by the environment (Liawa, \& Huang, 2013).

Interactive learning with increased control over the learning process can successfully simulate in person the learning model. Nevertheless, the success of this learning required adjustments in many areas, including the assessment and the expectations of society, and training instructors. In addition, the quality and control issues those need to be addressed in order to create a favorable environment for this learning process (Aggarwal \& Bento, 2000).

However, interactive learning developed knowledge based on people-centered invited to join in the learning process interactively with environmental conservation in the form of education, which emphasizes the importance of local-community organizations that can manage the interests and knowledge, empowering local communities, and accommodate local's participation in human development, ecological sustainability, and economic contribution (Dagron \& Tufte, 2006).

\section{Methodology}

This one and half years' quantitative research were conducted in the Seribu islands from January 2014 - August 2015. A randomly questionnaire was distributed to 200 respondents. The respondent from the government sides: Tourism, Forestry, and Regional Planning 


\section{Macrothink}

Environmental Management and Sustainable Development

ISSN 2164-7682

2015, Vol. 4, No. 2

Agency; District Administration; Local government; Department of Infrastructure; Department of Social and Environmental Impact Assessment; Regent staff. The rest: Tour operators; Local community; tourist; and the NGO. Each respondent was questioned five different times for their consistency (Jennings, 2001).

The research was carried out in four (4) phases: Firstly, pre-study, which was conducted from January 2014 through March 2014 for the study of literature and searched for information related to relevant agencies; Secondly, research conducted in April 2014 through November 2014 for the collection of data and information to responding to the purpose of the study; Thirdly, workshops and group discussions focused on the perception and identify the key factors (Krueger \& Casey, 2009) that were held in December 2014 through April 2015; and Forthly, tabulation data and report in May 2015 to August 2015.

The collected data was tabulated by the content analysis (CA) (Macnamara, 2005; Cohen, 1960; and Gottschalk, 2013) that focus on social-communication (Borrini-Feyerrabend, Farhar, Nguinguiri, \& Ndangang, 2007): Informing (Barwick, Phipps, Johnny, \& Myers, 2014); Raising awareness (Aall, 2014; and Dagron \& Tufte, 2006); Training (Tiger, Hanley, \& Bruzek, 2008); and Interactive learning (Dagron \& Tufte, 2006). Nevertheless, the CA of social communications (Gottschalk, 2013; Macnamara, 2005; and Cohen, 1960): Exploratory analysis; Posting each attribute; Frequency; Frequency counted; and Discussions. Each respondent was questioning five different times for their consistency.

\section{Results and Discussions}

Based on social communication and the research's tabulation (Table 1), this study found the actual social-communication is not significant (0.450). The existing priority of the program is starting from Informing, interactional learning, training, and raising awareness.

Table 1. Content analysis - existing social communication

\begin{tabular}{|l|r|r|}
\hline The Actual Social Communication - Seribu islands & Value & $\%$ Freq \\
\hline Informing & 23 & 0.2771 \\
\hline Raising awareness & 19 & 0.2289 \\
\hline Training & 20 & 0.2410 \\
\hline Interactive learning & 21 & 0.2530 \\
\hline
\end{tabular}

Kappa Coefficient $=0.4611$

Table 2. Content analysis - expected social communication

\begin{tabular}{|l|r|r|}
\hline The Expectation Social communication - Seribu Islands & Value & $\%$ Freq \\
\hline Informing & 24 & 0.2162 \\
\hline Raising awareness & 27 & 0.2432 \\
\hline Training & 29 & 0.2613 \\
\hline Interactive learning & 31 & 0.2793 \\
\hline
\end{tabular}

Kappa Coefficient $=0.6167$ 
While the expected communication (Table 2) is significant (0.9111), and the priority of the program is interactive learning, training, raising awareness, and informing. Broadly speaking, both tabulations indicated the gap in the communication program and the priority (Table 3 ). Proportionally, the information indicated over expectation, but the content of the information did not transfer yet to the local community. Moreover, to reach the goal of co-management, the program of raising awareness needs to be improved. Nevertheless, the training program seems would be improved as well as interactive learning program.

Table 3.

\begin{tabular}{|l|r|r|c|}
\hline The gap of social communication - Seribu Islands & Actual & Expectation & \multicolumn{1}{c|}{ Gaps } \\
\hline Informing & 0.2771 & 0.2162 & -0.0609 \\
\hline Raising awareness & 0.2289 & 0.2432 & 0.0143 \\
\hline Training & 0.2410 & 0.2613 & 0.0203 \\
\hline Interactive learning & 0.2530 & 0.2793 & 0.0263 \\
\hline
\end{tabular}

\% Kappa Coefficient Gaps $=0.1556(33.74 \%)$

In the context of "Informing," a lot of people who have not received information from the governments and non-governmental organizations, regarding potential endangered animals and habitat around the national park. At the same time, the government keeps trying to convey their information through posters and pamphlets. The indicators, the National Park of "Kepulauan Seribu," stated that they were still making efforts for the identification and monitoring of those listed in the 10 priority. Dolphins and mollusks are currently categorized as target identification. Besides Dolphins (Tursiops aduncus and Tursiops truncatus), there are other marine mammals too, such as sea turtles, mollusks, coral reefs, and mangroves. There are also a sea-grass, coastal forests, eagles, reef fish, and shorebirds (Yunus, 2015).

Moreover, holistic data collection and reorganization of the national park area will become the focus of work in the future. It also will coordinate internally to gather some important information related to the ecosystem in the island. By doing so, the more protected species and actions that disturb the habitat can be anticipated. Unfortunately, the data for these animals is not collected. While, the Department of Marine Science and Technology, Bogor Agricultural shows, there are two species of dolphins, which allegedly have habitat in the islands. It is Tursiops aduncus and Tursiops truncatus. Their appearance also increasingly frequents over the years. This important information did not clear yet to the community.

Furthermore, dolphins have long been known in the region, and during this, presence is not so considered. Attention on marine animals is much more devoted to turtles that already identified and conserved by the National Park. Turtle conservation, especially the hawksbill turtle (Eretmochelys imbricata), can be found on this island. The tourists can see straight up to feed the hawksbill in these places, and a turtle habitat used as the core zone of the national park (Jal, 2015a).

Factually, a number of activities in the island potentially threaten their existence, and the local community activities that can damage their habitat. Moreover, so far, there are no regulations related to the identification of the existence of this species. Allegedly, their 
habitats continue to be depressed. The pressure, increased as more massive coastal-tourism and local community activities that can potentially damage surrounding coastal habitat. Furthermore, so far there has been no identification of the regulations related to the existence of this species (Yunus, 2015).

Currently, the Islands have a number of problems that make the tourism potential offered does not develop optimally. One is the pollution of the sea from the region due to the amount of garbage and oil (Rachman, 2015). The indicators, waters in the "Pulau Seribu" National Park's area had been heavily polluted. The delegation of local officials caught two middle ships dispose of oil in waters near the island in the District of the Islands. Furthermore, there is a pool of oil out of the two ships, intentionally dumped into the water, and the oil spill that fouled the waters covering an area of approximately 2,000 square meters. Its potentially wider affected area because the oil is still out.

A disposal oil that occurs in the deep waters of the National Park area. A number of islands in the area, especially Penjaliran Island, were once nesting the habitats of hawksbill turtle (Eretmochelys imbricata) are protected because tend to be rare. Besides Penjaliran Island Penjaliran East and West, a number of islands are protected as well as a place that turtles lay their eggs, in the East of Peteloran Island and the island of The Belanda. Conservation areas, territorial waters and the environment also become an asset resident and tourism-related government programs. The national park is known to have unique natural resources, especially the underwater beauty and unequaled coral ecosystems. The wealth of marine life is also highly variable (Jal, 2015a; and Yunus, 2015).

In terms of raising awareness, the tourism sector development needs an integrated strategy that takes into account economic, socially, cultural, and environmental. It would increase the social-awareness of the coastal-tourism program based on the society, with growing tourism, without damaging the environment. Besides, it would increase the capacity of the social-change of the community's behavior in the development programs of the islands, the Government has not prioritized and promoting raise awareness of the human resources, sustainable coastal tourism, and the balance economic contributions by the conservation of the environment.

In fact, they are at once actors of development goals. Ideally, the development of the tourism sector is maximizing the potential of local resources. There is a shift in the community after tourism continues to grow. Ironically, the local population marginalized in the structure of the tourism business due to lack of capital, networks and knowledge. Not only that, in the capacity and capability is also not increased (Jal, 2015b).

The indicators, due to the high tourist arrivals on the island have been a negative impact on the environment, land degradation and threats to coral reefs. Coastal tourism patterns also ignore local residents and the development of community-based tourism or community. Moreover, in 2000, the data of the National Park demonstrated that the results of the initial survey on the condition of dive spots around the island still had a coral that covered more than 50 percent. However, in a survey in 2014, at the point 2-3 to dive from the 10 point dive in coral cover less than 25 percent (Jal, 2015b). 
Talking about the accessibility, the government is expected to be more aware of the importance of the development of infrastructure to support tourism, because local governments lag in various ways, such as transportation, water, electricity carrying capacity, and Waste Management.

On one hand, the tourism potential is very high. In 2015, the Administrative District of the island has a budget of USD 3:05 billion (Jal, 2015b). Most of the budget will focus on infrastructure development in order to encourage tourism regions. One infrastructure that becomes the focus is transportation by constructing a special harbor crossing to the island more representation at the gate of the tourist area, so that the port was built in the Bahtera Jaya, East Ancol, North Jakarta. On the other hand, the government has also tightened regulations for the safety of passenger ship's traditional-crossing, which has been the backbone of the transport residents.

In terms of training, the government did not support for their policy effectiveness. It affected the behavior problem that caused an environmental's destructive. The training would support the conservation efforts of the communication process on sustainable coastal tourism programs. While, on the island the government is carrying out and open all lines of communication with the public. The local government is also drawing up patterns of touch and training programs to the local community that has not been facilitated. Currently, the government is making matrix needs and plan regional program, which is being developed according to the needs of today's society. It was, among others, English language training for tour guides, teacher training for informal and self-employment programs.

One of the associations that develop coastal-tourism based on the concept of eco-tourism in the islands, was called Elang Ecotourism that development TERANGI Foundation. The associations consist of local people in the village Panggang Island, with different backgrounds but have the same principles and goals. An activity developed by the foundation is education, training, and coaching, scouting, and monitoring the condition of the coral reef ecosystems, environmental improvement or rehabilitation and restocking biota, and public awareness.

In terms of interactive learning, there is a Creative Village that located on the island, where the tourists can interactively learn firsthand about how to make paper from recycled materials properly, ranging from the preparation is done, until the appropriate paper making. After careful attention to the paper-making process, it needs attention, accuracy, and precision to produce papers, which have economic value and can be sold: frame, safe-deposit box, and so on.

Moreover, in the Island, there is a tourist center of education and marine conservation, which was managed by the National Park. In this place, tourists can learn and do nautical-tourism. For tourists who want to see and learn the cultivation of rare marine life, can find it in the Laboratory of Marine Life Species. The species is among other biota fish common bottlenose dolphin (Tursiops trucatus) and hawksbill (Eretmochelys imbricata). Nevertheless, interactive learning would be impressive in empowering both local community and the government program aims. Based on the people-centered program, the development of 
learning process assessment and the expectations of the society would be effective interactively on the environmental conservation program.

\section{Conclusions}

Based on the research finding, there is a significant gap (33.5\%) of social communications. The government could decrease the gap by aligning the priority of the communal communications. It would be done by starting their priority from interactive learning, training, and raising public awareness. At the same time, the government informing the program aim by using a social-media, an invitation to the local community in a synergistic learning program that would accommodate the idea, information, and the suggestion from the community.

As a note, in terms of social communication, this study found that interactive learning became the basic needs of the stakeholders in supporting co-management program. This study also recommended the government to use people-centered on supporting the program.

\section{Implications}

As mentioned before, on supporting the communal communications, the government gets to prioritize and enhance the environment, infrastructure and conservation programs, by fulfilling the coastal tourism needs for clean water supply and the construction of infrastructure and the electricity network on attracting the tourist.

In terms of interactive learning, it is the media of social communications that the government could accommodate many ideas from the local community. It would empower the community on the environmental conservation programs.

Moreover, on raising awareness on conserving the environment along coastal areas, the government would be developed it by inviting the local community to participate actively in the interactive learning program. At the same time, the government would enhance the program with the training program based on people-centered that effectively attract the participant sharing their ideas and needs.

While, to inform the program, the government would enhance the empowerment of the local community. It would be a pull motivation for the tourist to visit the coastal-tourism based on community participations.

Nevertheless, the government should consider simplifying the bureaucracy on licensing for the foreign tourists who visit the islands and increase planting to beautify sea coral reefs around the islands (Rachman, 2015).

There is a waste-disposal site in the protection zone bordering the core zone. The area is off-limits to the use and exploration activities, especially waste. It would be very dangerous for the protected biota. Damage to the reef or sea grass can also occur. Waste can as well be a negative impact on the tourism sector. Therefore, the waste will be carried by ocean currents to the beaches make the island aesthetics disturbed. A number of seaside activities, such as swimming or diving, will also be affected. 
Mangrove forests cleared for tourism facilities and as a result contributes it in sustainability way. If the entire forest area is cut down and used for the benefit of tourism as well as the exclusion of forest function itself, will bring negative impacts such as floods and landslides. Not only that, the development of tourism often displaces or disrupts the existence of sanctuaries, as well as the exclusion of customs and culture (Jal, 2015a)

\section{References}

Aziza, K. S. (2015). Ahok Will Make "Seribu Islands" International Standard, Compass. Retrieved from http://megapolitan.kompas.com/read/2015/08/19/16350171/Ahok.Bakal. Jadikan.Pulau.Seribu.Berstandar.Internasional

Aggarwal, A. K., \& Bento, R. (2000). Web-Based Education, Web-Based Learning and Teaching Technologies: Opportunities and Challenges, IGI Global. http://dx.doi.org/10.4018/978-1-878289-60-5.ch001

Aall, C. (2014). Sustainable Tourism in Practice: Promoting or Perverting the Quest for a Sustainable Development, Sustainability, 6(5), 2562-2583. http://dx.doi.org/10.3390/su6052562

Bandura, A. (2001). Social cognitive theory of mass communication. Media Psychology, 3(3), 265-299

Barwick, M., Phipps, D., Johnny, M., \& Myers, G. (2014). Knowledge Translation and Strategic Communications: Unpacking Differences and Similarities for Scholarly and Research Communications, Scholarly and Research Communication, 5(3), 3-8. Retrieved from http://src-online.ca/index.php/src/article/viewFile/175/344

Borrini-Feyerrabend, G., Farhar, M. T., Nguinguiri, J. C., \& Ndangang, V. A. (2007). Co-management of natural resources, Kasparek Verlag, Momchhofstr, 21-24.

Barwick, M., Myers, G., \& Coriandoli, R. (2014). Knowledge Translation and Strategic Communications: Unpacking Differences and Similarities for Scholarly and Research Communications, Scholarly and Research Communications. Scholarly and Research Communication, 5(3), 1-14.

Carlsson, L. \& Berkes, F. (2005), Co-management: concepts and methodological implications, Journal of Environmental Management, 75, 65-76. Doi: 10.1.1016/j.jenvman.2004.11.008

Cohen, J. (1960). A Coefficient of Agreement for Nominal Scales. Educational and Psychological, 20, 37-46. http://dx.doi.org/10.1177/001316446002000104

Dagron, A. G., \& Tufte, T. (2006). Communication for Social Change Anthology: Historical and Contemporary Readings, Communication for Social Change Consortium, Inc., 153-338

Gottschalk, L. A. (2013). Content Analysis of Verbal Behavior: New Findings and Clinical Applications, Routledge, 19-22

Krueger, R. A., \& Casey, M. A. (2009). Focus groups: A practical guide for applied research, 4th edition. Thousand Oaks, CA: Sage. 
Ostrom, E., \& Schlager, E., (1996). The formation of property rights, In: Hanna, S., Folke, C., Ma"ler, K.-G. (Eds.), Rights to Nature, Ecological, Economic, Cultural, and Political, Principles of Institutions for the Environment. Iceland Press, Washington, DC, 127-156.

Petty, R. E., Brinol, P., \& Priester, J. R. (2009). Mass media attitude change: Implications of the elaboration likelihood model of persusion. In Bryant, J. \& Oliver, M. B. (Eds). Media effects: Advance in theory and research (3rd ed). New York

Holtzhausen, D. \& Zerfass, A (2015). The Routledge Handbook of Strategic Communication, Taylor \& Francis, 94-110

IUCN. (1994). Guidelines for protecting Areas Management Categories, IUCN [International Union for Conservation of Nature and Natural Resources] - Commissions on National Parks and Protected Areas (CNPPA) - World Conservation Monitoring Centre (WCMC), Gland Switzerland and Cambridge, UK

Jal, M. (2015a). Heavy Polluted waters Jakarta, Kompas print. Retrieved from http://print.kompas.com/baca/2015/08/01/Perairan-Jakarta-Tercemar-Berat

Jal, M. (2015b). Pulau Seribu Need Integrated Strategies. Compass print. Retrieved from http://print.kompas.com/baca/2015/05/09/Kepulauan-Seribu-Perlu-Strategi-Terpadu?utm_sou rce=bacajuga

Jennings, G. (2001). Tourism Research, John Willey \& Sons Australia, Ltd., 136-152.

Kuslum, U. (2015). Remove Bad Impression of the :Seribu Iskands. Kompas print. Retrieved from

http://print.kompas.com/baca/2015/02/25/Menghapus-Kesan-Buruk-Kepulauan-Seribu?utm_ source=bacajuga

Liawa, S., \& Huang, H. (2013). Perceived satisfaction, perceived usefulness and interactive learning environments as predictors to self-regulation in e-learning environments, Computers \& Education, 60(1), 14-24. http://dx.doi.org/10.1016/j.compedu.2012.07.015

Macnamara, J. (2005). Media content analysis: Its uses, benefits and Best Practice Methodology, Asia Pacific Public Relations Journal, 6 (1), 1- 34. Retrieved from http://amecorg.com/wp-content/uploads/2011/10/Media- Content-Analysis-Paper.pdf

Mediana (2015). Structuring Urgent Tourism Infrastructure, Kompas. Retrieved from http://print.kompas.com/baca/2015/03/19/Penataan-Infrastruktur-Pariwisata-Mendesak

Rachman, D. A. (2015). Rizal Ramli Push "Seribu Islands" Tourism Center Maritime So Indonesia, Kompas. Retrieved from http://nasional.kompas.com/read/2015/09/09/15261371/ Rizal.Ramli.Dorong.Kepulauan.Seribu.Jadi.Pusat.Wisata.Maritim.Indonesia

Sukmana, Y. (2015). Here are 10 areas to be boosted Sightseeing Government, Economics. Retrieved From http://bisniskeuangan.kompas.com/read/2015/09/14/211900826/Inilah.10.Destinasi.Wisata.ya ng.Akan.Digenjot.Pemerintah?utm_source=news\&utm_medium=bp-kompas\&utm_campaign 


\section{Macrothink \\ Environmental Management and Sustainable Development \\ ISSN 2164-7682 2015, Vol. 4, No. 2}

$=$ related $\&$

The World Leisure (2008). Leisure: Enhancing the human condition, The World Leisure organization's strategic plan for the period 2009-2014, 16-20. Retrieved from www.worldleisure.org

Tiger, J. H., Hanley, G. P., \& Bruzek, J. (2008). Functional Communication Training: A Review and Practical Guide, Behavior Analysis Spring, 1(1), 16-33. Retrieved from http://www.ncbi.nlm.nih.gov/pmc/articles/PMC2846575/

UNICEF (2005). Strategic Communication - for Behaviour and Social Change in South Asia, The United Nations Children's Fund, Nepal, 37-78

Wahono, T. (2015). Marine Transportation Nightmare "Pilau Seribu," Megapolitan. Retrieved from http://megapolitan.kompas.com/read/2015/06/17/1634334/Mimpi.Buruk.

Transportasi.La

Wahyuni, T. (2013). Seribu Islands tourism continues to be addressed, Travel. Retrieved from http://travel.kompas.com/read/2013/10/03/1547189/Pariwisata.Kepulauan.Seribu.Terus.Berbe nah?utm_source=bisniskeuangan\&utm_medium=bp-kompas\&utm_campaign=related\&

Weiss, J. A., \& Tschirhart, M. (2007). Public information campaigns as policy instruments, Journal of Policy Analysis and Management, 13(1), 82-119. http://dx.doi.org/10.2307/3325092

Win, W. (2015). Foreign tourist arrivals to Indonesia Record Record High, CCN Indonesia. Retrieved from http://www.cnnindonesia.com/gaya-hidup/20150403155216-269-44067/kunjungan-wisatawa n-asing-ke-indonesia-catat-rekor-tertinggi/

Yunus, S. R. (2015). Down the Jakarta Bay, Greet herd dolphins, Compass print. Retrieved from

http://print.kompas.com/baca/2015/08/25/Menyusuri-Teluk-Jakarta,-Menyapa-Kawanan-Lum ba-lum

\section{Copyright Disclaimer}

Copyright for this article is retained by the author(s), with first publication rights granted to the journal.

This is an open-access article distributed under the terms and conditions of the Creative Commons Attribution license (http://creativecommons.org/licenses/by/3.0/). 